\title{
Cloning goes to the movies
}

\section{A clonagem vai ao cinema}

\author{
Craig Cormick \\ Manager of Public Awareness \\ Biotechnology Australia \\ craig.cormick@biotecnology.gov.au
}

CORMICK, C.: Cloning goes to the movies. História, Ciências, Saúde - Manguinhos, v. 13 (supplement), p. 181-212, October 2006.

Public attitude research conducted by Biotechnology Australia shows that one of the major sources of information on human reproductive cloning is movies. Traditionally, understanding of new and emerging technologies has come through the mass media but human cloning, being so widely addressed through the popular culture of movies, is more effectively defined by Hollywood than the news media or science media. But how well are the science and social issues of cloning portrayed in box office hits such as The Island, Multiplicity, Star Wars: Attack of the Clones and Jurassic Park? These movies have enormous reach and undoubted influence, and are therefore worth analyzing in some detail. This study looks at 33 movies made between 1971 and 2005 that address human reproductive cloning, and it categorizes the films based on their genre and potential influence. Yet rather than simply rating the quality of the science portrayed, the study compares the key messages in these movies with public attitudes towards cloning, to examine the correlations.

KEYWORDS: science and movies; cloning and movies.

CORMICK, C.: A clonagem vai ao cinema. História, Ciências, Saúde - Manguinhos, v. 13, (suplemento), p. 181-212, outubro 2006.

Pesquisa de opinião pública conduzida pela Biotechnology Australia mostra que o cinema é uma das maiores fontes de informação sobre clonagem humana. Tradicionalmente, o conhecimento de tecnologias emergentes se dá através dos meios de comunicação, mas a clonagem humana, sendo tão amplamente difundida pela popular cultura cinematográfica, é definida por Hollywood de forma faz eficaz do que pelos noticiários ou publicações científicas. Mas como é que as questões sociais e científicas da clonagem são retratadas em sucessos de bilheteria como A Ilha, Multiplicidade, Guerra nas Estrelas: Ataque dos Clones e Parque dos Dinossauros? Esses filmes tiveram grande alcance e influência inquestionável e, portanto, merecem uma análise mais detalhada. O presente estudo examina 33 filmes sobre clonagem humana feitos entre 1971 e 2005 e classifica os filmes por gênero e potencial de influência. No entanto, em vez de simplesmente avaliar a qualidade da ciência retratada, o estudo compara as mensagens-chave desses filmes com a opinião pública frente a clonagem, a fim de examinar correlações.

PALAVRAS-CHAVE: ciência e cinema; clonagem e cinema. 
1 MARS, Australian Community Opinion Survey:

Biotechnology,

Human Stem Cell and

Gene Technology,

Market Attitude

Research Services

(telephone poll of

1000 adult

respondents,

conducted for

Biotechnology

Australia), 2002, 2003,

2004, 2005, and 2006;

Eureka Strategic

Research, Public

Awareness Research

(telephone poll of

1067 adult

respondents and 17

focus groups

conducted for

Biotechnology

Australia), 2005.

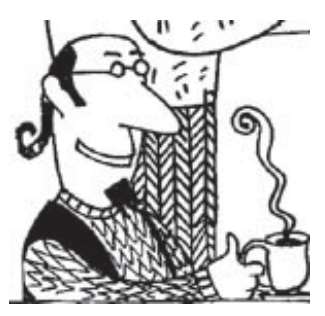

$\mathrm{P}$ ublic attitude research conducted by Biotechnology Australia ${ }^{1}$ shows that one of the major sources of information on human reproductive cloning is movies. In general the public has strong concerns about human reproductive cloning which are reinforced, or mirrored, by the portrayal of cloning in movies - whether that be through mad scientists, bad science or immoral corporations - themes that are duplicated many times in the movies studied.

If you believe what you read in the tabloid newspapers, the first human clones came into existence in 2002 - one procedure was performed by the Italian doctor Severino Antinori, and the other by Clonaid, the company formed by members of the Raelian movement.

If you follow the scientific literature however, no human clones have yet been born because cloning, in addition to being illegal in most countries, is not yet advanced enough to succeed with higher primates.

Yet cloning is all around us and is very real in the public imagination - largely through the portrayal of human cloning in Hollywood films. Over twenty films in the last 15 years alone have addressed human cloning.

Cloning has in fact been happening for many hundreds of years if we consider the cloning of plants through taking cuttings. And cloning of animals has been happening since 1952, when tadpoles were cloned - followed by animals including a cat, dog, mice, pigs, sheep, cows and a rhesus monkey.

Human reproductive cloning, while not possible in practice, has been portrayed in movies since the 1970s - with varying degrees of accuracy, and often fairly fantastical in terms of what cloning may possibly achieve.

Quite a lot has been written about the inaccuracy of physics in films like Star Wars and Star Trek (Krauss, 1998), but there has not been any similar analysis of the science of biotechnology in movies. In recent movies there has been an increase in the portrayal of the dangers of genetic modification, particularly in horror films that focus on it as out-of-control, such as Frankenfish (2004), Komodo (1999), Flying Virus (2001) and 28 Days Later (2002). In fact the dangers of nuclear radiation have been replaced in several remake movies with the dangers of genetic manipulation. In the remake of Spiderman (2002) he acquires his powers after being bitten by a genetically modified spider as opposed to a radioactive spider, and in the remake of The Hulk (2003) he acquires his powers as a result of his father's experiments on genetic manipulation, as opposed to gamma radiation.

In all of these films the accuracy of the representation of biotechnology impacts are greatly exaggerated for the benefit of the drama, and so concerned are many scientists about this that an Oxford Don has set up a consultancy agency to Hollywood to counter negative portrayals of scientists in big budget films. 


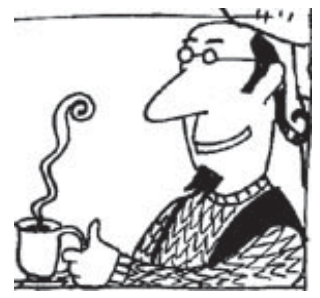

Doctor Lizzie Burns of Oxford's department of Biochemistry said, "In Die Another Day (2002) the explanation of gene therapy for the villain changing his face is so wrong it's unbelievable. We want to help them avoid big blunders, and make their films more credible" (The Oxford Student, 2005).

In fact movies have a very long tradition of taking liberties with scientific accuracy. In George Méliès' 1902 film A Trip to the Moon, six adventurers are sent to the moon in a capsule fired from a large cannon. In a memorable scene the capsule crashes into the eye of the moon, and the explorers then encounter moon people who kidnap them. After escaping back to their capsule, the moon people push them off the moon and they fall back to earth, landing safely in the ocean.

Another study, of 222 movies that portrayed science, conducted by Weingart, Muhl and Pansegrau, found that the most alarming scientific depictions related to "modification of, and intervention into, the human body, the violation of human nature, and threats to human health by means of science."

They stated that, "The threat is dramatized by being associated with the image of the scientists as pursuing the quest for new knowledge in secrecy, outside the controls of academic institutions and peer" (Weingart, Muhl \& Pansegrau, 2003).

This study focuses on just one aspect of biotechnology - human cloning, and reviews 33 movies made between 1973 and 2005 that address human reproductive cloning. This study compares the quality of the science being portrayed in these movies and the associated key messages relating to trust in science and regulation. The findings are then compared to public attitudes towards cloning to determine if there are any correlations.

The movies have been divided into five distinct categories, based both on genre and credibility of the messages portrayed, as Christopher Rose, who uses movies to teach biology at James Madison University in the USA, has said, "realistic movies provide more engaging and through-provoking entertainment than ones that violate obvious and well-understood scientific principles" (Rose, 2003).

1. Contemporary Social Realism - those set in, or very near to, the present and presented as realistic.

1.1 The Boys From Brazil (1978)

1.2 Jurassic Park (1993)

1.3 The Lost World: Jurassic Park (1997)

1.4 Cloned (1997)

1.5 Blue Print (2002)

1.6 Godsend (2004) 
2. Future Social Realism - those set in the future but presented as realistic.

2.1 The 6th Day (2000)

2.2 Yesterday (2002)

2.3 The Island (2005)

3. Science Fiction/Fantasy - those set "long, long ago in a galaxy far away" or in the far future.

3.1 Judge Dredd (1995)

3.2 Neon Genesis Evangelion (1995-1996)

3.3 The Fifth Element (1997)

3.4 Alien Resurrection (1997)

3.5 Star Wars: Attack of the Clones (2002)

3.6 Star Trek: Nemesis (2002)

3.7 Natural City (2003)

4. Comedy - those using cloning as the cornerstone of comedy in the film.

4.1 Sleeper (1973)

4.2 City of Lost Children (1995)

4.3 Multiplicity (1996)

4.4 Austin Powers: The Spy Who Shagged Me (1999)

4.5 Austin Powers in Goldmember (2002)

4.6 Repli-Kate (2002)

4.7 Clone High (2002)

5. Gone and forgotten - those films on cloning that did not rate well at the box office, or are rarely seen anymore.

5.1 Resurrection of Zachary Wheeler (1971)

5.2 The Clones of Bruce Lee (1977)

5.3 The Clonus Horror (1979)

5.4 Anna to the Infinite Power (1982)

5.5 Creator (1985)

5.6 The Cloning of Joanna May (1991)

5.7 Replikator: Cloned to Kill (1994)

5.8 The Third Twin (1997)

5.9 Shadow Fury (2001)

5.10 The Adventures of Pluto Nash (2002)

While primarily U.S.-produced, the above list includes two movies made in Korea (Yesterday and Natural City), one made in Hong Kong (The Clones of Bruce Lee), one German-Turkish coproduction (Blue Print), one French film (City of Lost Children) one Japanese Anime series (Neon Genesis Evangelion), one British television dram (The Cloning of Joanna May) and one animated TV series (Clone High).

Analysing the movies for which there is data on cost and return, 16 films dealing with cloning cost in excess of US\$ 1 billion to 
produce, at an average cost of US\$ 67 million per film - an enviable amount compared to most science communications budgets.

\begin{tabular}{|c|c|c|c|}
\hline Released & Movie Name & $\begin{array}{l}\text { Worldwide } \\
\text { Takings \$US }\end{array}$ & $\begin{array}{l}\text { Budget } \\
\text { \$US }\end{array}$ \\
\hline 1973 & Sleeper & $\$ 18,344,729^{*}$ & $\$ 2,000,000$ \\
\hline 1978 & The Boys from Brazil & $\$ 19,000,000^{*}$ & $\$ 12,000,000$ \\
\hline 1993 & Jurassic Park & $\$ 920,100,000$ & $\$ 63,000,000$ \\
\hline 1995 & Judge Dredd & $\$ 85,000,000$ & $\$ 113,487,000$ \\
\hline 1996 & Multiplicity & $\$ 20,133,326^{*}$ & $\$ 45,000,000$ \\
\hline 1997 & The Fifth Element & $\$ 263,900,000$ & $\$ 95,000,000$ \\
\hline 1997 & The Lost World: Jurassic Park & $\$ 786,686,679$ & $\$ 75,000,000$ \\
\hline 1997 & Alien: Resurrection & $\$ 160,700,000$ & $\$ 60,000,000$ \\
\hline 1999 & $\begin{array}{l}\text { Austin Powers: The Spy } \\
\text { Who Shagged Me }\end{array}$ & $\$ 309,600,000$ & $\$ 35,000,000$ \\
\hline 2000 & The 6th Day & $\$ 34,543,701$ & $\$ 82,000,000$ \\
\hline 2002 & Austin Powers in Goldmember & $\$ 213,079,163$ & $\$ 63,000,000$ \\
\hline 2002 & Star Wars: Attack of the Clones & $\$ 648,200,000$ & $\$ 115,000,000$ \\
\hline 2002 & The Adventures of Pluto Nash & $\$ 7,094,995$ & $\$ 100,000,000$ \\
\hline 2002 & Star Trek: Nemesis & $\$ 67,312,826$ & $\$ 60,000,000$ \\
\hline 2004 & Godsend & $\$ 16,910,708$ & $\$ 30,000,000$ \\
\hline \multirow[t]{3}{*}{2005} & The Island & $\$ 160,799,026$ & $\$ 120,000,000$ \\
\hline & Totals: & $\$ 3,731,405,153$ & $\$ 1,070,487,000$ \\
\hline & Average & $\$ 233,212,822$ & $\$ 66,905,000$ \\
\hline
\end{tabular}

* U.S. figures only available; Source: The Numbers: Box Office Data.

The concern that these movies have a large impact on people's attitudes is exemplified by the U.S. bioethicist, Arthur L Caplan, who said of the movie Godsend, "Thanks Hollywood. Just as people were beginning to understand cloning, you have put greed before need and made a movie that risks keeping ordinary Americans afraid and patients paralyzed and immobile for many more years" (Caplan, 2004).

He also stated that a problem with being given misinformation about cloning was that it polluted the debate about making cloned embryos for research, particularly stem-cell research (ibid.).

According to surveys conducted by Biotechnology Australia, the Hollywood media is most cited as a source of information on human reproductive cloning, and focus group discussions indicate that those films that depict realism have more impact than those films that are satirical or science fiction and fantasy. 
One focus group respondent even stated:

I saw a movie once, and it was sort of a very factual movie, where this couple cloned this child, and the child was traveling fine, until it got to about 14 or 15 years of age, and this child was gifted, super intelligent and had a lot of things going for it, and then all of the sudden the whole body system went ballistic, it went through an aging process, it started getting all these diseases in the world and that kid died... They based that movie on real events they could see happening. (Focus Group, conducted by Market Attitude Research Services, Sydney, 2004)

The reference appears to be towards the film Godsend, which is a fictitious film, although it went to great pains through its promotional activities to depict a medical institute with its own web site and hotline where human cloning was taking place (Duncan, 2004). So if social realism films can sometimes be confused with factual representations of cloning, it is therefore important to analyse the key messages being portrayed in those films in particular.

The following section provides a brief plot synopsis for the 33 movies listed and rates the accuracy of the science as well as the morals and regulation with which the science has been portrayed.

\section{Contemporary Social Realism Movies}

\subsection{The Boys from Brazil (1978)}

Staring Gregory Peck, Laurence Olivier and James Mason, and based on the novel by Ira Levin, this movie tells of a plot by the Nazi 'Angel of Death', Joseph Mengele, to clone Adolph Hitler. He has a laboratory in a remote location in Brazil where he has conducted experiments on live subjects, finally succeeding in producing 94 cloned boys, who have been born around the globe. Recognising the importance of environmental inputs to the formation of a child's personality, the parents have been chosen for their similarity to Hitler's (an aged father and young mother etc.). As the boys turn 15-years-old, the father in each family must be killed in what appears to be an accident - as Hitler's own father had died. This, however, becomes the trigger for the unraveling of the plot.

The science in the film is very accurate, and even includes a scene in a German research institute where the process of cloning is meticulously explained, using rabbits. Laurence Oliver received an academy award for best actor for his role as Ezra Lieberman, based on the real life Nazi hunter Simon Wiesenthal.

Best scene: A wounded Dr. Mengele to one of the young cloned Adolf Hitlers: "You are the living duplicate of the greatest man in history. Adolf Hitler!" The boy in reply: "Oh, man. You're weird." 
pretty hostile to DNA. Instead of letting us assimilate some other living thing's DNA into our own, the stomach quickly breaks down the long, delicate double helix into small fragments. That makes them hard to put back together. Worse, the mosquito's own DNA would get mixed in. Putting together complete dinosaur DNA would be pretty much impossible" (Platt, 2002).

Best Scene: Richard Attenborough: "All major theme parks have had delays. When they opened Disneyland in 1956, nothing worked, nothing." Jeff Goldblum: "But if the Pirates of the Caribbean breaks down, the pirates don't eat the tourists."

Best Lines: Tim: "What do you call a blind dinosaur?" Sam Neil: "I don't know." Tim: "A Do-you-think-he-saurus."

Accuracy of the science: Moderate. The film takes some creative leaps, such as the abilities to use frog DNA with dinosaur DNA.

Key message: The films depicts a good scientist whose work is corrupted by others. The moral tone of the films is that tinkering with nature is obviously dangerous.

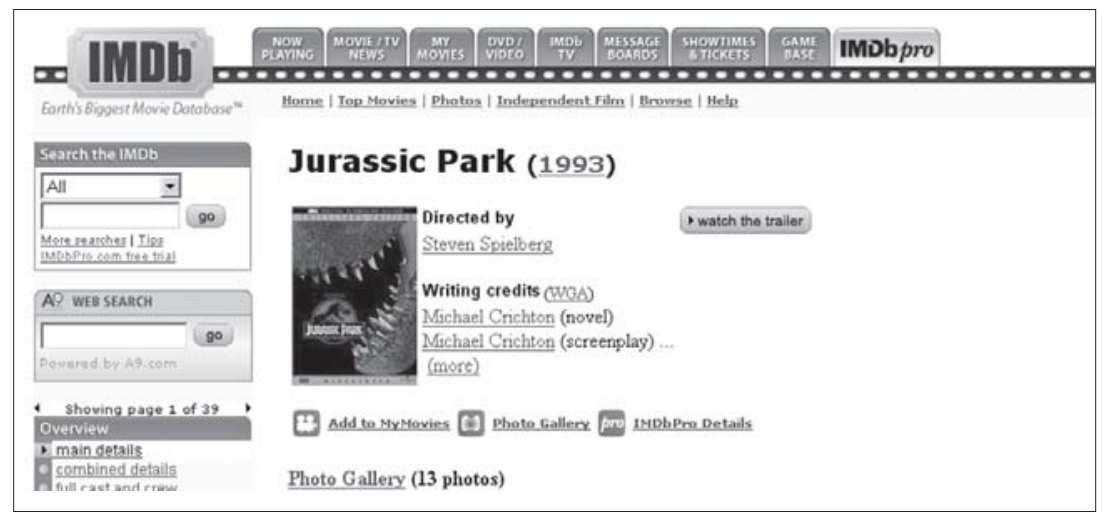

http://amazon.imdb.com/title/tt0107290/

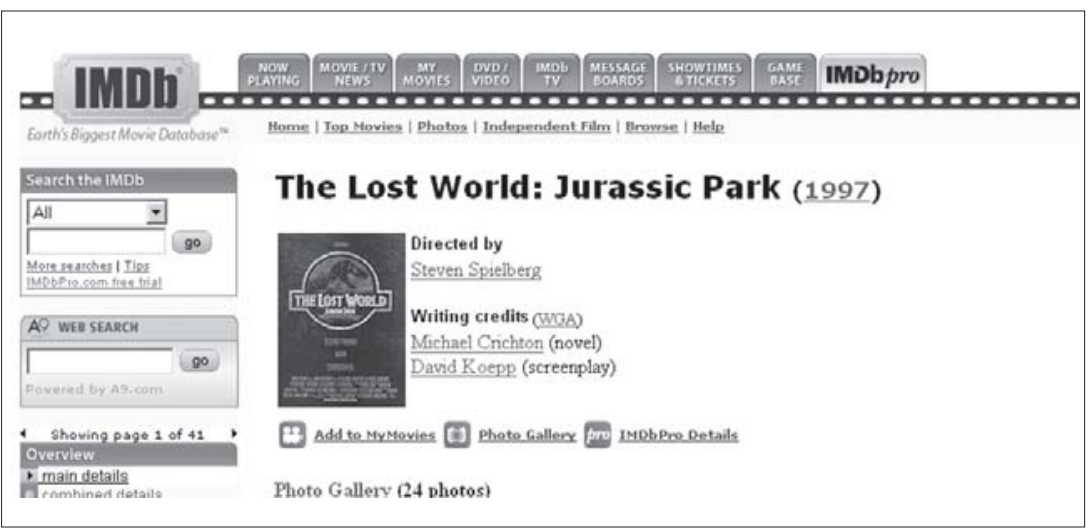

Available at http://amazon.imdb.com/title/tt0119567/ 


\subsection{Cloned (1997)}

This telemovie is one of the few films that has a fairly accurate portrayal of the science of cloning. Set in the year 2008 the film stars Elizabeth Perkins as the mother of boy who has died at the age of eight in a boating accident. Some time later she sees her son, or a boy who is identical to her son, and she discovers that an immoral scientist working for the fertility clinic that helped her conceive has cloned her son. She confronts the doctor and is faced with the dilemma of whether to report them, or to have another child from the same genes of the child she lost. If she refuses to co-operate with the doctor, however, she knows her life will be in danger.

Best scene: Voice over on trailer: "What she never counted on was discovering that while science could create miracles and doctors were the new gods... those miracles could become nightmares... and those new gods were really monsters."

Accuracy of the science: High.

Key message: Scientists operating outside of regulation in their own interests are willing to kill to cover up what they've done.

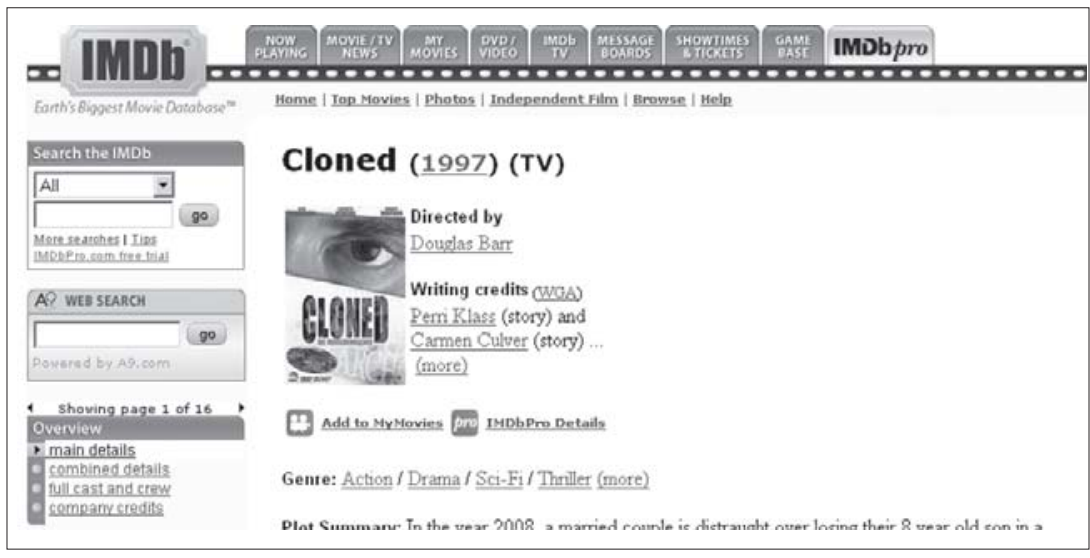

Available at http://amazon.imdb.com/title/tt0126245/

\subsection{BluePrint (2002)}

One social realist film that deserves special mention is the German film Blue Print. The story revolves around Iris, a renowned concert pianist who discovers she has Multiple Sclerosis, something that will cut her career short. In order to preserve her talents she approaches a fertility expert to have herself cloned - which is illegal in the film. She gives birth to her cloned daughter named Siri, and we see her raised from a young girl through to an adult, including the point at which Siri discovers she is a clone and how that effects her self-image. 
This film is one of the most scientifically realistic yet does not dwell on the science, as it focuses mainly on the social issues of being a clone. It looks at the impact of nature and nurture on whether or not Siri wishes to turn her talents to music as her mother has done. A very thoughtful film, though not one that achieved a wide international distribution.

Best scene: Siri pins a yellow Star of David to her clothes, with the word Clone written on it.

Accuracy of the science: High. The science is very accurate, with the cloned daughter being implanted in the mother to be born.

Key message: The science and its morals are less an issue than the relationship between the mother and daughter, and how being a clone of one's mother might impact upon a person, as well as how being a clone could lead to ostracism from society.

\subsection{Godsend (2004)}

In the movie Godsend, Paul (Greg Kinnear) and Jessie's (Rebecca Romijn-Stamos) child, Adam, dies in an accident when he is only eight-years-old. They are devastated, but a kindly and caring scientist, played by Robert de Niro, offers to replicate their beloved son for them through cloning.

Though illegal, the couple agree and soon give birth to another son who is identical to their first, and who they also name Adam. But as the cloned Adam reaches the age at which the first Adam died, strange things begin to happen. The movie has a strong sense of horror/thriller about it. It is slowly revealed that the scientist placed some DNA from his own dead son into the couple's cloned child, in an attempt to also bring back his son. Interestingly, there are several optional endings on the DVD version of the film, so the viewer can actually choose an ending that is happy or tragic, depending on how they want the story to end, but regardless of the ending there is a strong sense of the immorality of cloning. The film's promotion features the strap line: "Evil is here!"

Best scene: Greg Kinnear to Robert De Niro: "I swear to God I'll tell the whole goddamned world what you've done!"

Robert DeNiro back to Greg Kinnear: "What we've done, Paul. What weeeeeeeeeee've done!"

Accuracy of the science: Moderate.

Key message: Cloning, although illegal, can be conducted by immoral scientist, who pretend to be good but are actually quite immoral, strongly driven by personal gain.

With the exception of BluePrint, which provides a considered reflection on human cloning, all the social realism films reviewed depict mixed messages about the science of cloning, and even when 
the science is accurate it is often simplified greatly. Squeezing a complex science and associated ethical issues into two hours or less, obviously necessitates short cuts. But even those films like Jurrasic Park and The Boys from Brazil, that include segments within the film designed to educate the audience about cloning, portray the science as being easy to hijack by immoral interests.

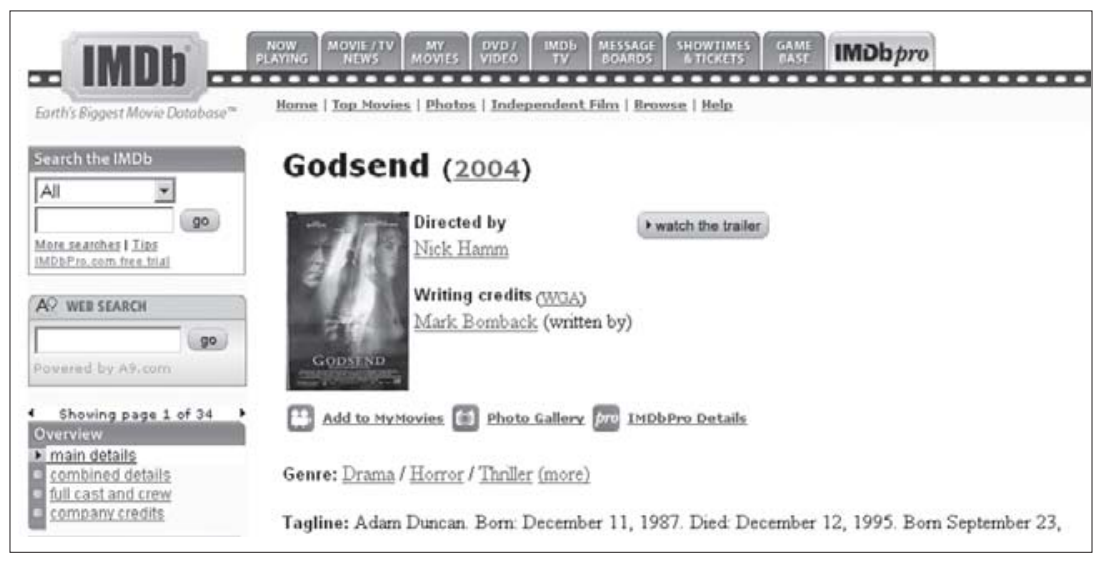

Available at http://amazon.imdb.com/title/tt0335121/

\section{Future Social Realism}

\subsection{The 6th Day (2000)}

Beginning with the benign cloning of deceased family pets, this film becomes a fast-paced action thriller to uncover the fact that a large corporation is illegally cloning humans (including the head of the corporation itself). Adam Gibson (played by Arnold Schwarzenegger) is accidentally cloned after he is thought to have died in a helicopter accident, leading to two Adam Gibsons (which means two Arnold Schwarzeneggers) - one of which must be murdered to cover up is the illegal cloning. The science is undertaken by a well-meaning scientist, played by Robert Duvall, but it is all funded and controlled by the evil director of a large immoral corporation.

Best scene: Drucker, the evil head of the Drucker Corporation, cloning himself after being fatally wounded and his malformed clone stealing his clothes before he's dead.

Accuracy of the science: Very low. The science is very misleading, as full human clones are created in a very short space of time, with a person's DNA being encoded into a 'blank' body, and the memories then being downloaded from a mini-CD.

Key message: Corporations operating outside of regulation in their own interests are willing to kill to cover up what they've done. 


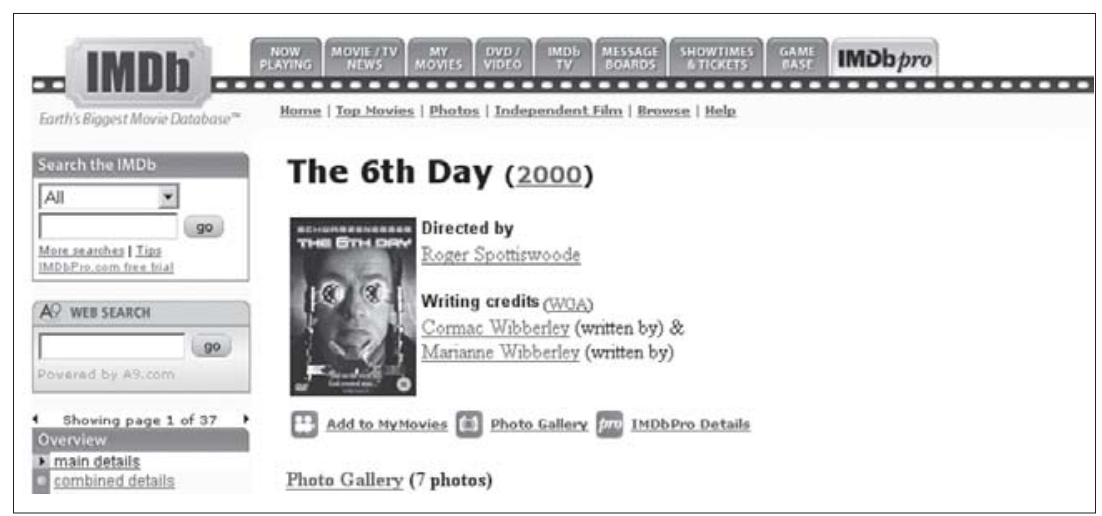

Available at http:/ / amazon.imdb.com/title/tt0216216/

\subsection{Yesterday (2002)}

In the year 2020 unification of the Korean peninsula has occurred. The film is an action thriller with a special police branch trying to solve the killing of prominent scientists. What initially appears to be a case of domestic terrorism turns out to be a cover up of a large cloning experiment conducted years before,.

Best scene: Female police scientist: "The human genome must be studied because we are the origin of all common evil."

Accuracy of the science: Moderate.

Key Message: Cloning is unnatural and has bad outcomes, and those behind it will go to extreme lengths to cover it up.

\subsection{The Island (2005)}

The Island is set in the near future, in the year 2019, with the two lead characters Lincoln Six-Echo, played by Ewan McGregor, and Jordan Two-Delta, played by Scarlett Johansson, being in an elite facility where they do nothing but keep fit and healthy and do a little bit of learning. As the plot unfolds, Lincoln Six-Echo discovers that he's a clone and that the institution, Merrick Biotech, is there to maintain healthy body organs for the original humans that they have been cloned from. They tell the clones that they have won a lottery in order to go to the Island - which is the only unpolluted place left on earth.

Lincoln Six-Echo's curiosity gets the better of him and he enters a restricted part of the facility to find that not all is as it seems. He then escapes the facility with Jordan Two-Delta and finds the outside world is far beyond his imagination - with the corporation trying to kill them to prevent anybody finding out about them. From there it becomes a high-tech chase film - but this shows how 
Lincoln and Jordan react to being told they're clones and the morality of the corporation that has produced them.

Best scene: Steve Buscemi, advising Lincoln Six-Echo and Jordan Two-Delta not to seek out their original humans: "Just cause you wanna eat the burger, doesn't mean you wanna meet the cow."

Accuracy of the science: Low, as full human beings are cloned.

Key message: Corporate scientists operating outside of regulation in their own interests are willing to kill to cover up what they've done.

The predominant message from the realism films is that cloning is conducted by evil scientists or immoral corporations, without effective regulation. This aligns closely with public attitudes found in studies conducted by Biotechnology Australia, which show that people feel the science of cloning is being pursued for no justifiable reason, but purely in the name of science (Public Awareness Research, 2005).

Added to this is the high-profile controversy of South Korean researcher Hwang Woo-Suk having falsified data, and concern that the high public condemnation and disrepute of human reproductive cloning will flow on to all forms of research that involve some type of cloning. The screenwriter of the film Godsend, Mark Bomback, responded to Nature's criticism of the film's portrayal of science by saying his film should not be understood as a critique of science or an attack against cloning human embryos for research. "It would mortify me if it was used to condemn stem cell research," he said ("Science goes Hollywood", 2004).

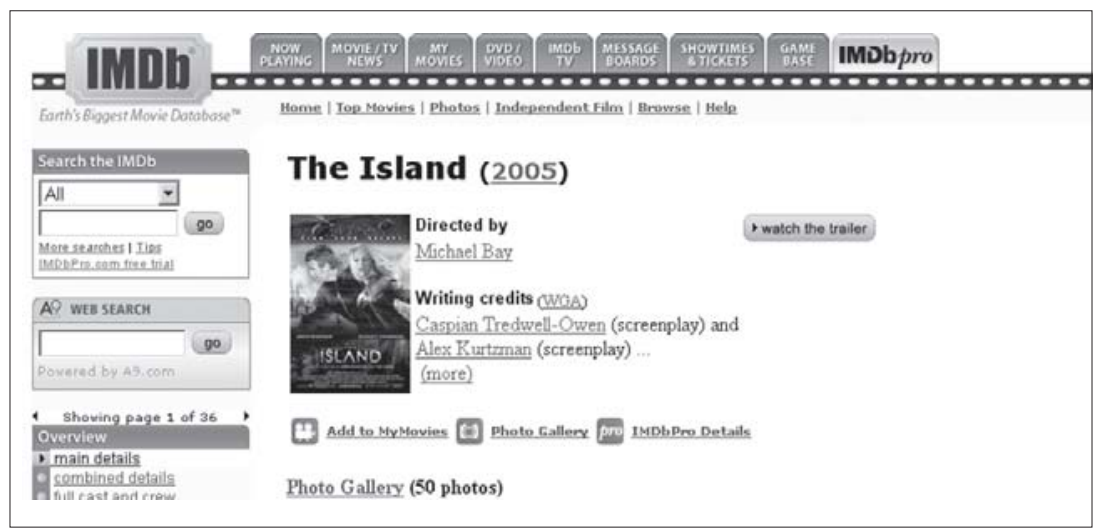

Available at http://amazon.imdb.com/title/tt0399201/ 


\section{Science Fiction/Fantasy}

Most science fiction films that have biotechnology components have much more fiction than science in them, but by being set in the future it is possible for the films to make imaginative claims that cannot easily be contradicted on what the science might be able to achieve. Consequently, the accuracy of the science in these films is not rated.

In these films though, cloning invariably tends to have been undertaken for dubious moral purposes. Little attention is paid to individual scientists, as the science tends to be undertaken by large organizations. The only film in this category that shows a benign form of cloning is the Fifth Element, where the 'supreme being' is cloned from the remains of her hand.

Cloning in these films tends to be very advanced and conducted for sinister reasons,

\subsection{Judge Dredd (1995)}

In Judge Dredd, Sylvester Stallone plays the comic book hero Judge Dredd, who has been cloned from the deceased law-enforcer Joe Fargo with added cybernetic eyes. The film was a huge commercial failure and the film rating web site rottentomatoes.com gives it a rotten tomato rating of $18 \%$.

Best scene: None worth mentioning.

Key message: Clone a mean cop and you might get a meaner cop.

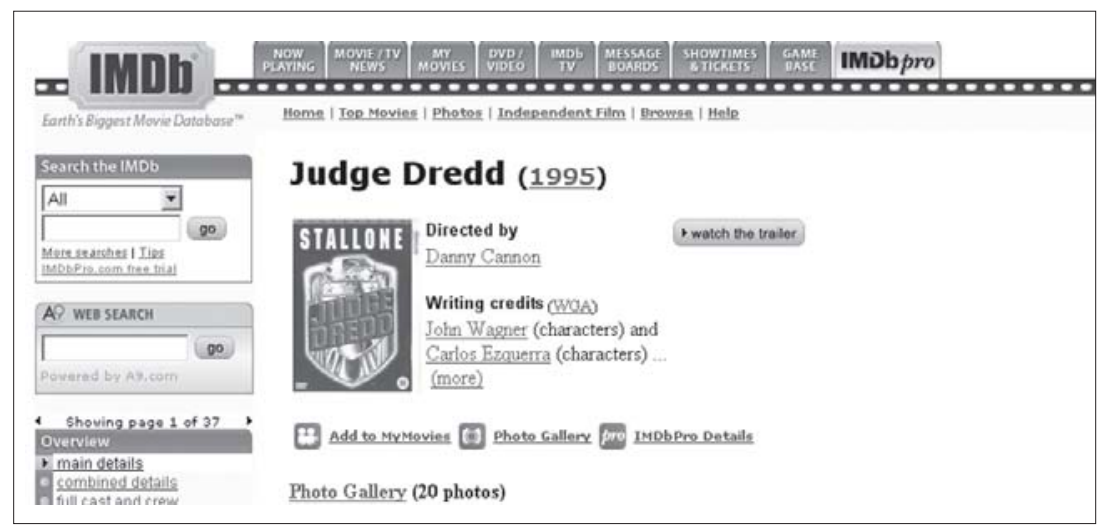

Available at http://amazon.imdb.com/title/tt0113492/

\subsection{Neon Genesis Evangelion (1995-1996/1997 and 1998)}

This Japanese anime television series was recut and released as two movies in 1997 and 1998. Set in the year 2015, the Earth is 
under assault from strange monsters referred to as Angels. The only defence against them are the biomechanical mechas. One of the lead characters Rei Ayanami has three clones, Rei I, Rei II and Rei III who battle the Angels with her.

Best scene: Any of the battle scenes for male viewers. Any of the angst and identity scenes for female viewers.

Key message: Clones may appear human, but are not always accepted as fully human.

\subsection{The Fifth Element (1997)}

The Fifth Element, staring Bruce Willis, Milla Jovovich and Gary Oldman and directed by French director Luc Beson is a highly imaginative comic film, set in the year 2263. The survival of humanity depends on the 'supreme being' who has been destroyed by the forces of evil. All that remains of the supreme being is a hand in a glove. Thanks to the miracles of future cloning technology, the hand is put into a chamber and the whole body of the supreme being is recreated from it. The supreme being is then able to do battle against the forces of evil, with Bruce Willis' help, and save the world.

Best scene: Milla Jovovich being instantly cloned from her hand inside the replication chamber.

Key message: Cloning is useful and can be used to restore severely injured bodies.

\subsection{Alien Resurrection (1997)}

In Alien Resurrection, the lead character, Ellen Ripley, played by Sigourney Weaver, has been secretly cloned to separate her DNA from an Alien's DNA. Ellen had previously been 'infected' with an alien, and given birth to one in the third Alien film, Alien ${ }^{3}$, just at the point when she killed herself and the alien.

This film begins with us seeing Ripley being born as an adult clone, and her violent reaction to the scientists who have cloned her. The alien is also cloned, several times, and things invariably go wrong and the alien escapes, destroying the space station and the evil scientists who run it.

It is never explained how the alien's DNA might have mixed with her own, nor how she has some of the alien's strength and acid-like blood in her veins without it eating through her skin. The film's director, Jean-Pierre Jeunet, had used clones as a theme in his earlier film The City of Lost Children (La Cité des Infants Perdus) (1995). 
Best scene: Ripley discovers a room where experiments containing seven preserved unsuccessful attempts at cloning and separating her and the Alien - each is half-Ripley and half-Alien grotesquely mixed, including one that is still alive, begging to be killed.

Key message: When immoral scientists fiddle with nature they get their insides ripped apart by savage aliens.

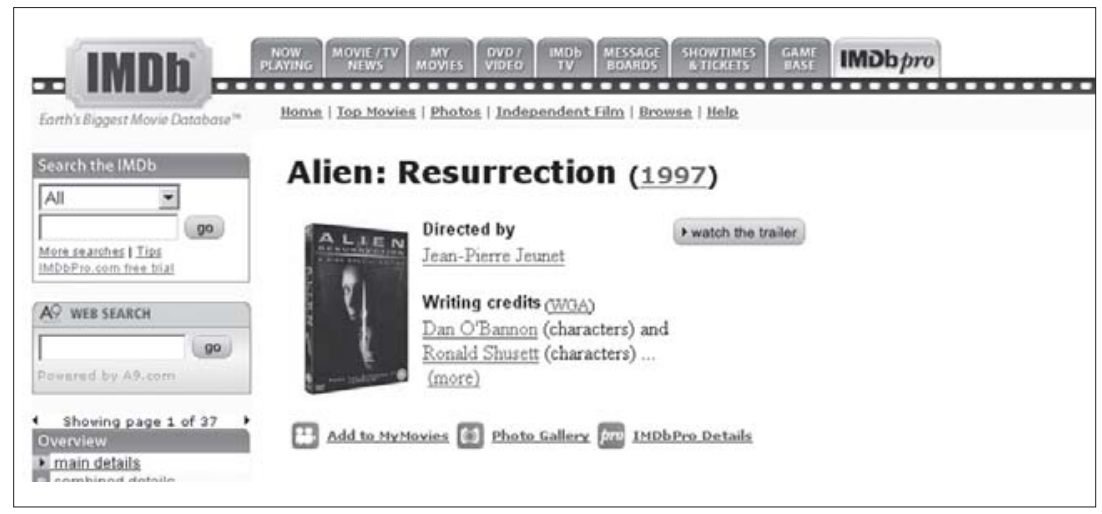

Available at http://amazon.imdb.com/title/tt0118583/

\subsection{Star Wars: Attack of the Clones (2002)}

This is billed as the second film in the Star Wars series, though the fifth film made. Most of the principal photography for the movie was shot in Australia. The film stars Ewan McGregor, Natalie Portman, Hayden Christensen and Christopher Lee. The premise for Star Wars: Attack of the Clones is that the Republic needs to create a secret cloned army to protect them - using the genetic code of a bounty hunter named Jango Fett. For if you can clone a person once, why not clone him a thousand times? Of course the questions it then raises are, who controls this army of clones and how will they be used?

Best Scene: Yoda flipping and jumping through the air to do battle with the baddies.

Key Message: Having the technology to make an army of clones is the easy part - having the ability to control them is much harder. Once unleashed new technology can be difficult to control. 


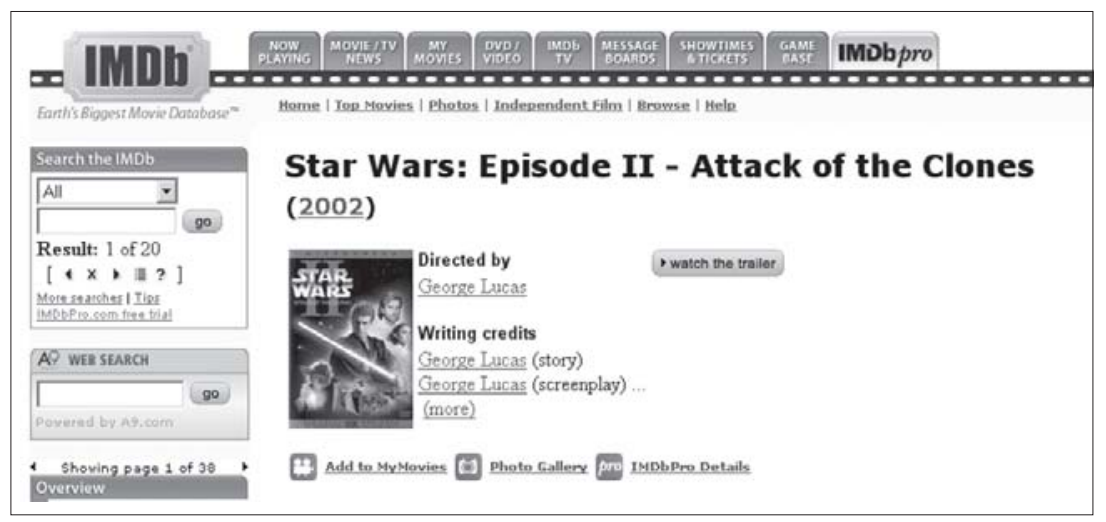

Available at http://amazon.imdb.com/ find? $=$ all\&q=Star+Wars\%3A+Attack+of+the+Clones +

\subsection{Star Trek Nemesis (2002)}

Star Trek Nemesis, though not one of the most successful of the Star Trek movie series, this film looks seriously at the issue of cloning beyond the technology. The plot involves a clone of Captain Jean Luc Picard taking over the Romulan Empire by a coup. The clone, Shinzon, is the mirror opposite to Picard in nature, because of his upbringing within the harsh Romulan empire. He is cruel and scheming and he wishes to destroy his original, Captain Picard. The film is low on action, but high on issues, such as what does it mean to be human.

The film rating web site rottentomatoes.com gives this film a rotten tomato rating of $40 \%$.

Best scene: Captain Picard, after meeting Shinzon: "I need to know where the hell he came from!"

Key message: Clones can be evil and want to get rid of the human they were cloned from.

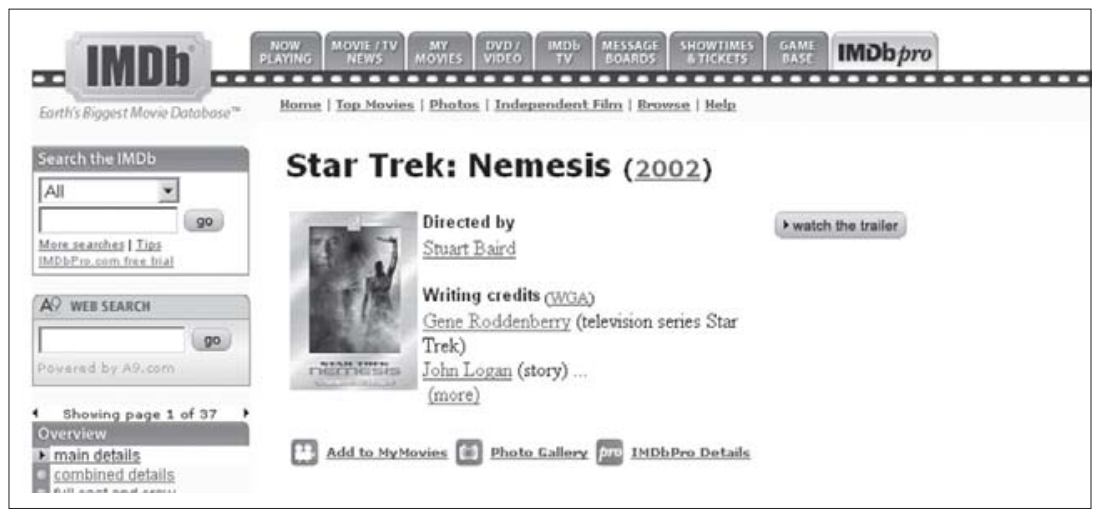

Available at http:/ / amazon.imdb.com/title/tt0253754/ 


\subsection{Natural City (2003)}

In this Korean film, a policeman falls in love with a clone - but clones have an artificially shortened lifespan and he's trying to find a way to keep her alive. Why not just reclone her, you might ask? This film is based closely on the groundbreaking Ridley Scott film Blade Runner (1982). It's a fast-paced action film, and it portrays clones as second-class citizens, but dangerous when they go rogue.

Best scene: Knowing that her dying is causing $R$, the policeman who loves her, pain, Ria, the cyborg clone, reaches up to the back of her head and pulls out the implant device and slumps to the floor lifeless.

Key message: Clones are second-class citizens with no rights.

Looking at the Science Fiction/Fantasy films in total, we see cloning portrayed as immoral science, and most of the cloned products are 'not natural' or are dangerous in some way.

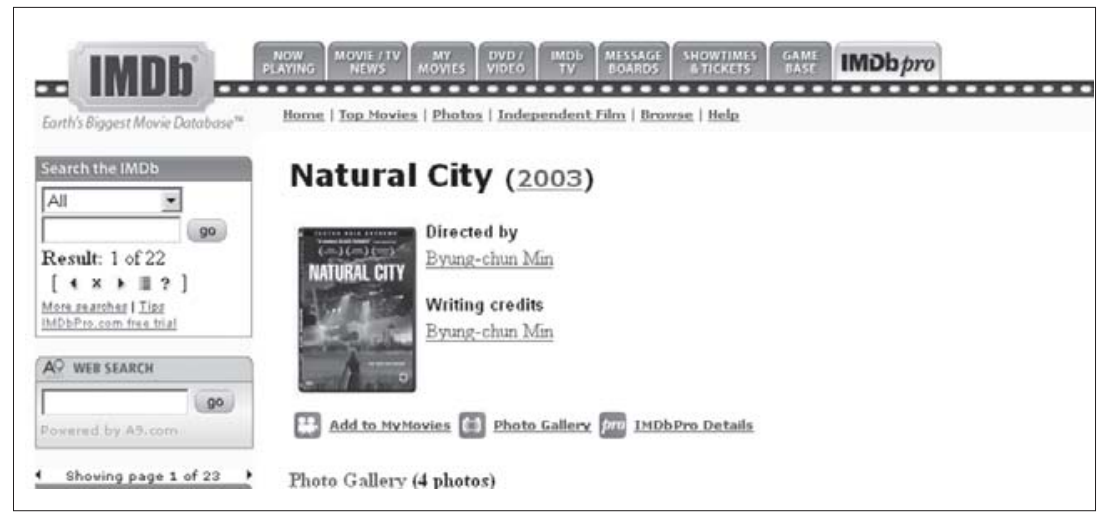

Available at http://amazon.imdb.com/title/tt0378428//

\section{Comedy}

Comedy and satire films seek to use cloning as the cornerstone of their comedy. Cloning is generally undertaken to generate a humorous situation and the scientists tend to be either mad, or at least eccentric. Doron Weber, the director of the Alfred P Sloan Foundation's Public Understanding of Science and Technology Fund classifies three types of scientists featured in Hollywood movies: the mad scientist, the bumbling scientist and the hopeless nerd ("Film Scientists Not all mad, bad", 2003). The scientists in the comedy films fulfill all three of these roles. Doctor Evil, from the Austin Powers films, even fills multiple roles, as being both mad and bumbling. 


\subsection{Sleeper (1973)}

Woody Allen is like Rip Van Winkler, waking 200 years into the future into a totalitarian state - ruled by the remains of the Great Dictator - his nose - which is all that is left of him after an attempt to do away with him by assassins from the rebel underground. Towards the end of the film Woody Allen is sneaking into a hospital, in an attempt to kidnap the Great Dictator's Nose, impersonating a doctor, when he is asked to clone the great dictator back from his nose.

Best scene: Hoping into a 200-year-old Volkswagen and starting it first go.

Accuracy of the science: Low.

Key message: If you need to clone your leader from his nose, don't let anybody steal it.

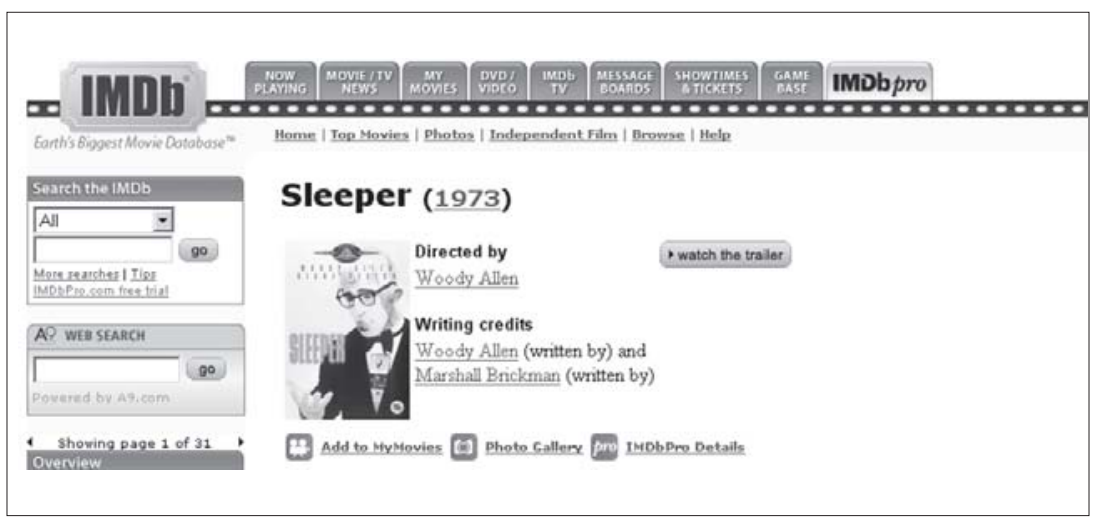

Available at http://amazon.imdb.com/title/tt0070707/

\subsection{City of Lost Children (La Cité des enfants perdus) (1995)}

This French film is more a dark satire than a comedy, and has multiple themes of twins, duality and clones throughout. The story is based around mad scientist who is kidnapping children in order to steal their dreams. A simple-minded strongman (Ron Perlman) and the girl leader of an orphan gang (Judith Vittet) set out through the surreal world about them to rescue the children. The scientist has made five clones of himself (all played by Dominique Pinon) who bicker over who is the original, and he has tried to engineer a wife, which went wrong, resulting in a small Bride of Frankenstein type character. The film is quite unique, and both captivating and disturbing, though not without moments of great humour.

Best scene: The clones all sitting around a birthday cake singing happy birthday. 
Accuracy of the science: Low.

Key message: If you make five clones, you'd better tell them who the original was or they will spend their entire lives fighting about it.

\subsection{Multiplicity (1996)}

In Multiplicity an overworked family man, played by Michael Keaton, makes a clone of himself to fulfill all his roles in life - father, husband, worker - but even that proves not quite enough - so he makes a second clone - who then goes out and clones himself and as we all know from our experience with the photocopy machine - a copy of a copy is never as good as the original - and that third clone is a bit dumb - providing extra comic relief. Two things of interest in the film, firstly the clones are made as fully formed adults and ultimately his clones want to do away with him and take over his life and be with his wife, played by Andie MacDowell.

The film rating website rottentomatoes.com gives it a rotten tomato rating of $44 \%$.

The geneticist Lee Silver has said that films like Multiplicity that show people being copied, consciousness and all, are responsible for much of the public misunderstanding of the science of cloning (cited in Nottingham, 1999).

Best scene: Michael Keaton hopping into bed with Andie MacDowell and discovering that he's already there.

Accuracy of the science: Very low.

Key message: Mess with nature and it will most likely mess with you.

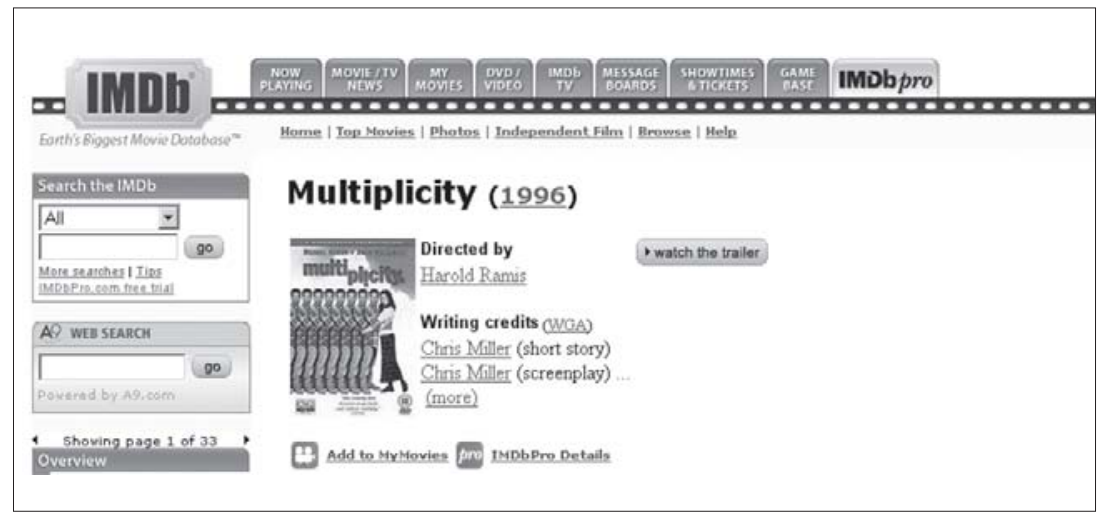

Available at http://amazon.imdb.com/title/tt0117108/ 
4.4 Austin Powers: The Spy Who Shagged Me (1999) and

4.5 Austin Powers in Goldmember (2002)

Austin Power: The Spy who Shagged Me introduced the character Mini-Me - who demonstrates how cloning can go wrong by forming an imperfect physical copy. The film addresses some of the issues of sibling jealousy that a clone might create between a human and his clone and his son. In the sequel, Goldmember, Mini-Me turns against Doctor Evil and works with, and dresses like, Austin Powers.

Best scene: Frau Farbissina introducing Mini-Me: "Send in the clone!"

Accuracy of the science: Low.

Key Message: Maintaining a working relationship with your clone and child at the same time as trying to take over the world can be extremely difficult.

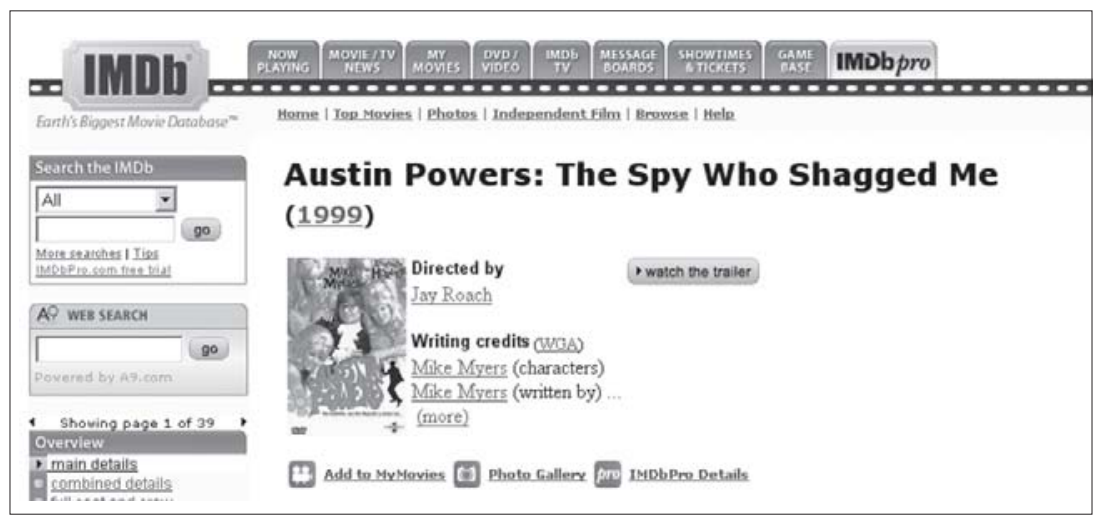

Available at http://amazon.imdb.com/title/tt0145660/

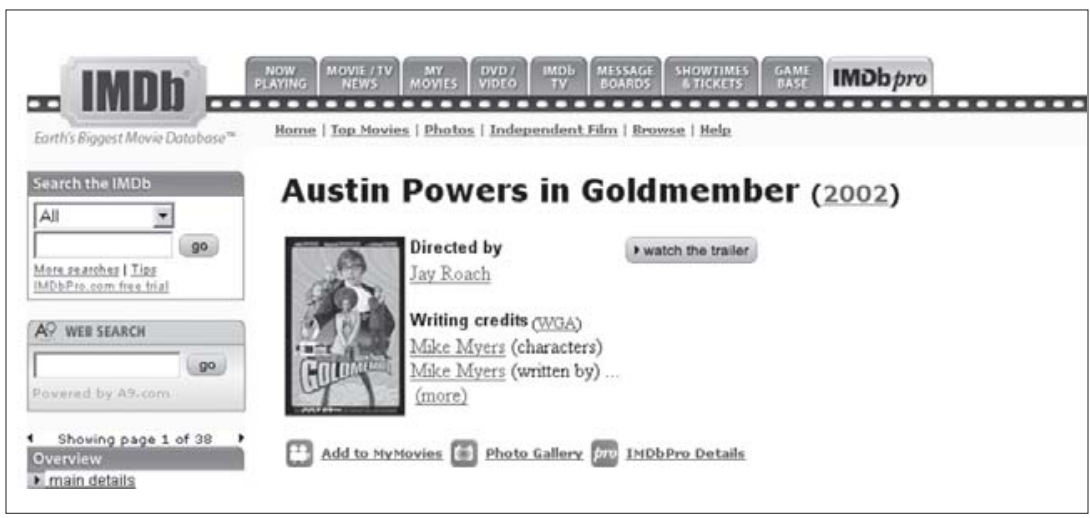

Available at http://amazon.imdb.com/title/tt0295178/ 


\subsection{Repli-Kate (2002)}

A geeky lab technician falls for a glamorous reporter and accidentally clones her. He then teaches her to behave like a beerdrinking football-watching one of the boys, but is torn between being attracted the real Kate or her clone. Very much teen-humour throughout, as typified by the best scene below, or with Kate and her clone walking around in their skimpy underwear and being mistaken for each other.

Best scene: Introducing a scientist from a European genetics firm called Gen-Italia

Accuracy of the science: Very low.

Key message: Like science is sooooo awesome because you can like totally clone hot babes, dude.

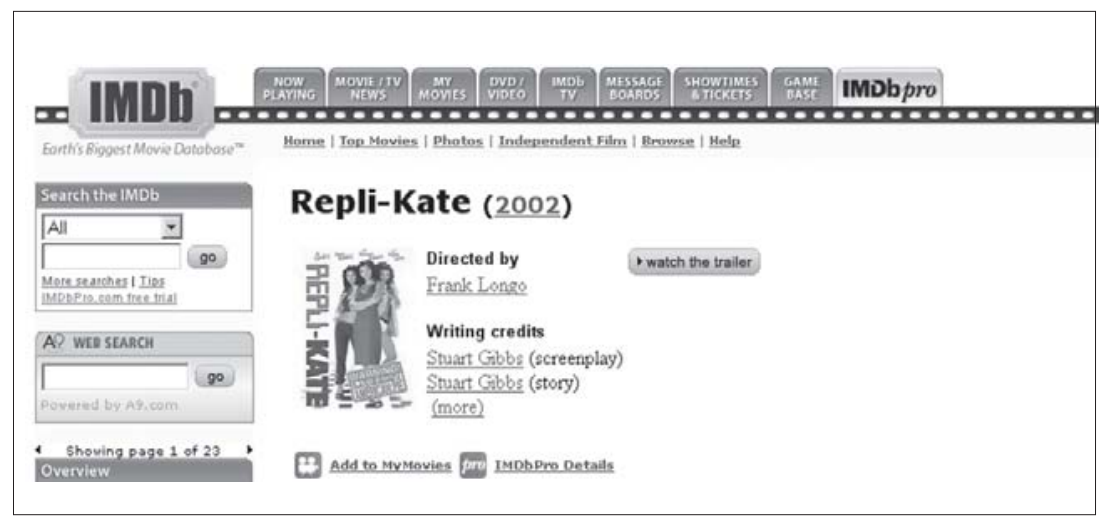

Available at http://amazon.imdb.com/title/tt0260320/

\subsection{Clone High (2002)}

This is a popular MTV cartoon series, based on the concept of a secret government experiment to clone famous people from history and observe them as teenagers at high school. The clones include Cleopatra, Abraham Lincoln, Joan of Arc and Gandhi. The satirical portrayal of Gandhi as the class hyperactive nerd even sparked emotive protests in India - where the show is not actually broadcast.

The clones are being closely monitored by the mad scientist, Principal Scudworth, and the Board of Shadowy figures, who both have their own agendas. the Board is hoping to model advanced soldiers and Principal Scudworth wants to open a clone theme park.

Best scene: Young Abe Lincoln standing under a picture of Abraham Lincoln being assassinated by John Wilkes Booth, saying 
he's very uneasy about standing for class president, but he can't exactly say why,

Accuracy of the science: High.

Key message: Even clones of famous people will behave like teenagers when in their teenage years.

There are few evil scientists in these films. They are more often well-meaning but unaware of the trouble they are causing. The science of cloning is rarely accurate in these comedy films, with full-grown clones that are the same age as the original (except in Clone High), being produced near instantaneously, and there is next to no regulation or control over the creation of clones.

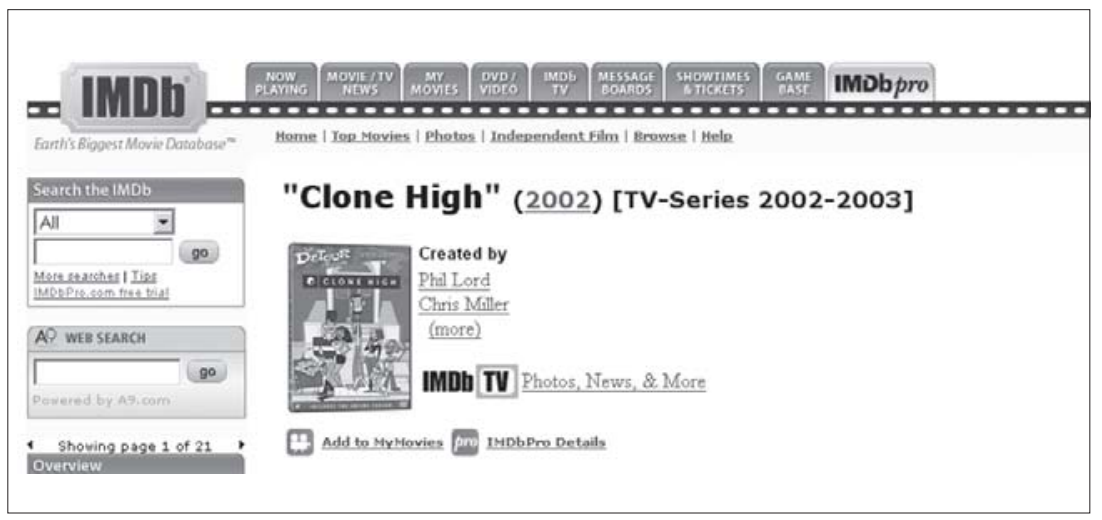

Available at http://amazon.imdb.com/title/tt0305011/

\section{Gone and forgotten}

Those films classed as gone and forgotten tend to have little impact on public attitudes, but merit some mention. Most of the films use cloning as central to the plot, and rate B- or lower.

\subsection{Resurrection of Zachary Wheeler (1971)}

The earliest cloning movie in this study, the plot revolves around a secret clinic where people are offered near-miraculous cures. When Senator Zachary Wheeler is seriously injured in a car accident he wakes up in the clinic to find that he has had several organs replaced. This is the first of many revelations about a secret plot to make mindless clones ('somas') of important people that can be used to provide them with compatible organ transplants - in exchange for certain favours. Investigative reporter Harry Walsh, however, played by Leslie Nielsen, stumbles upon the plot and sets about to uncover it. 
Worst scene: Transmitting human DNA code over a modem.

Accuracy of the science: Low. Human 'blanks' receive a DNA chain that makes them identical to the donor, as in the Island.

Key message: Immoral scientists and corporations create clones for profit.

\subsection{The Clones of Bruce Lee (1977)}

This film was actually made four years after Bruce Lee's death in 1973, cashing in as a Bruce Lee film without Bruce Lee in it by having clones of him in it instead. Several actors, who almost look like Bruce Lee, were employed to play his clones (Bruce Lee wannabes, Bruce Le, Dragon Lee and Bruce Lai). It is also possibly one of the worst cloning films ever made and is so bad it even defies a rotten tomato rating.

The clones are created by very primitive special effects that come down to flashing coloured lights and a metal head piece. They are then brain-washed by the mad and evil scientist to do his bidding, which includes working for the British government to assassinate several crime bosses.

Best scene: Evil scientist while making the Bruce Lee clones: "Ah-ha ha ha - Aha ha ha ha!"

Accuracy of the science: Very low.

Key message: Immoral scientist creates clones for own personal gain.

\subsection{The Clonus Horror (1979)}

The Plot for this film is very similar to The Island - a Corporation is cloning people to use for body parts for the rich. One clone escapes and threatens to bring the corporation down, but they subdue him with lethal doses of bad acting and bad dialogue.

Talking about making the film, producer Robert Fiveson, said, "Anybody can do a science fiction film run-clone-run, but to try and invoke some humanity into it, and to try and make the clone somebody you care about, that was the challenge that would make it more than a run-clone-run film. That might also have been its downfall. Maybe it was too earnest."

The trailer for the film ends with the line: "The motion picture that will steal your heart, and your liver, and your eyes and you kidneys..."

Best scene: Old lady in whose house the escaped clone has sought help. "Clone? Now where have I heard that? Clone? Oh - now - 
Jake, do you know what a clone is? Oh, I know what it is - I know what it is... I was reading in the Digest the other day and there was an article about a tadpole..."

Accuracy of the science: Low, as full human beings are cloned.

Key message: Corporate scientists operating outside of regulation in their own interests are willing to kill to cover up what they've done.

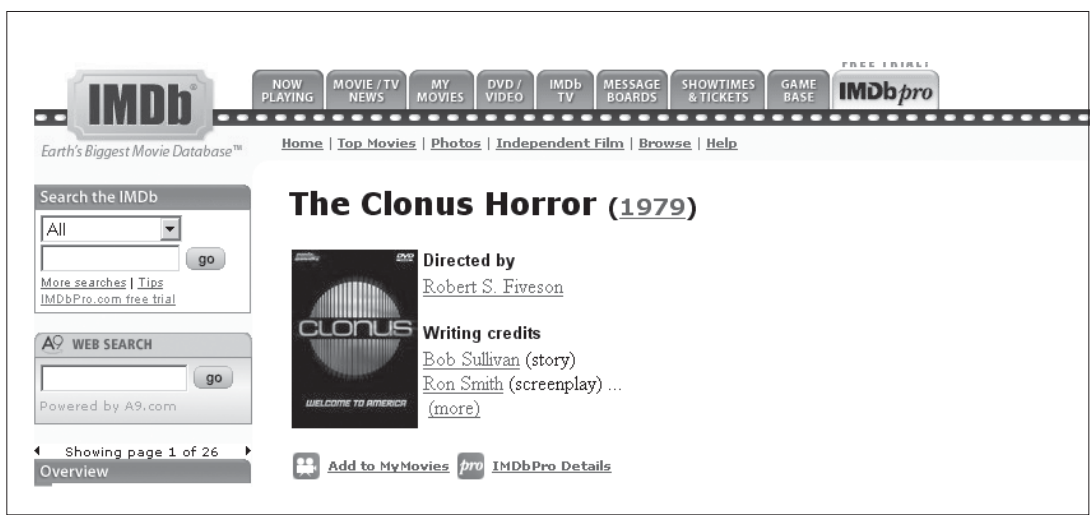

Available at http://amazon.imdb.com/title/tt0078062/

\subsection{Anna to the Infinite Power (1982)}

Anna is a 12-year-old child prodigy who is a genius at maths. She is also very arrogant and a kleptomaniac. One day she sees a girl on TV who is the identical image of her. Slowly Anna discovers that she is one of several clones of a brilliant physicist, Anna Zimmerman, who died before she could complete her research into a matter replicator. Several clones were made in the hope of being able to continue the research, but the institute that cloned her now consider that the experiment a failure and decides they will need to get rid of the clones.

Best scene: Anna, upon discovering that she's a clone: “I'm not a human being, I'm an experiment!"

Accuracy of the science: High.

Key message: Corporate scientists operating outside of regulation in their own interests are willing to kill to cover up what they've done.

\subsection{Creator (1985)}

Peter O'Toole plays Nobel Prize-winning scientist Doctor Harry Wolper whose wife died 30 years ago, and he is obsessed with trying 
to clone her. He finally succeeds in secretly creating a cloned embryo, but is discovered by the university before he can grow it to a foetus stage. The plot is padded out with romance, comedy and an improbably happy ending involving a much younger beautiful woman and some pretty mediocre acting.

Best scene: Harry's graduate student, while helping him steal a DNA sequencer from the University: "Let me tell you something about trying to regrow your dead wife. It's probably illegal, potentially dangerous and definitely crazy!"

Accuracy of the science: High.

Key message: Why try and clone your deceased wife when a 19year-old nymphomaniac wants you to marry her?

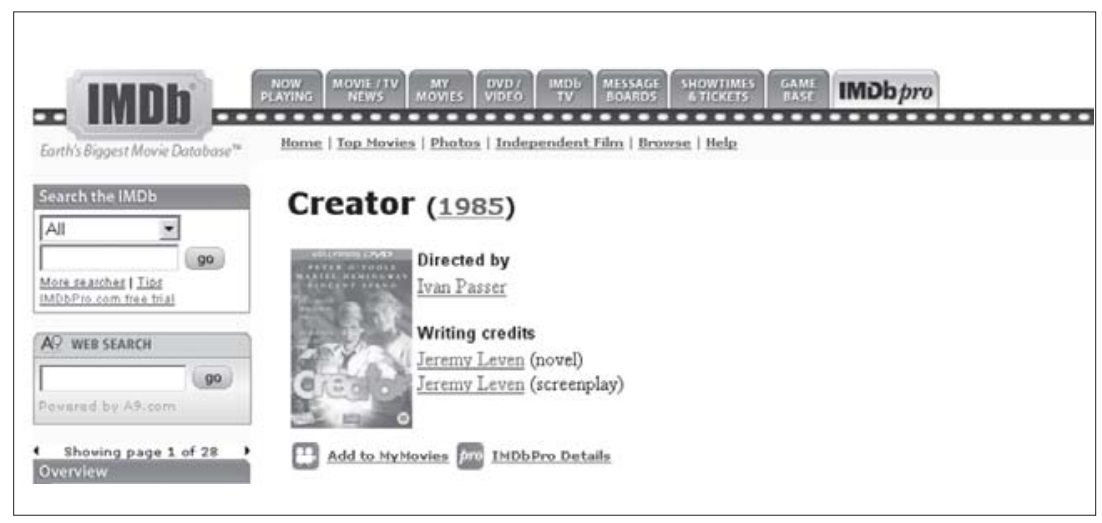

Available at http://amazon.imdb.com/title/tt0088960/

\subsection{The Cloning of Joanna May (1991)}

A British Granada Television program, based on the book by Fay Weldon. The story revolves around sexual betrayal and fantasy. Carl May makes three clones of his wife, Joanna, after he throws her out of his life for cheating on him - but he is so fixated on her that he waits until the clones of her have grown up so that he can choose Joanna anew as a young woman again. The clones, however, played by three women who look similar but not really identically, reject him.

Best scene: The three clone girls somehow not realising how similar they all are when they come together for the first time, until they are standing in their black lace knickers in front of a mirror and then wonder if they are triplets of each other.

Accuracy of the science: High.

Key message: Cloning a female lover is a nice fantasy - but it will most likely backfire in reality. 


\subsection{Replikator: Cloned to Kill (1994)}

A ruthless criminal boss gets control of technology to clone people, and a street-wise cop and his two cyberpunk friends have to try and stop him. A very B-grade film with a cameo by Italian actor and politician Cicciolina as a virtual reality erotic character. According to Cold Fusion Video Review, "Maybe the REAL Replikator movie is out there somewhere, and this one is only the unstable replicated copy" (Shumate, 2002).

Least lame scene: One of the lead characters is knocked unconscious in a fight and ends up inside a physical replication machine. When he wakes up, to his surprise, there's another one of him walking around.

Accuracy of the science: Very Low.

Key message: Don't get accidentally cloned, because your clone might turn out to behave like an evil twin.

\subsection{The Third Twin (1997)}

Based on a book by thriller writer Ken Follett this over-long film follows the story of Doctor Ferrami, a 'psycho-biologist', who is conducting twin studies to try and isolate a criminal gene. As she finds one exact look-alike after another of one of her subjects she stumbles upon a cover-up of a 27-year-old cloning experiment. She takes an inordinate amount of time to twig to this, however, and it makes you want to shout at her, "Don't you get it? They're not triplets, quadruplets or quintuplets - they're clones!"

The bad guy is played by Larry Hagman (J. R. from Dallas) who implanted the clones in women undergoing assisted reproductive technology. He knows his clones have violent psycho tendencies, but is trying to sell his company, Genetico, and needs to keep the cloning experiments secret so as to not jeopardise the sale.

Best scene: Doctor Ferrami to Doctor Jones (Hagman) at his press conference to announce the sale of Genetico: "My God, if the world went into a fury when they found we cloned a sheep, just think how they'll react when they find out you've been cloning human beings!"

Accuracy of the science: Very good, though not well explained.

Key message: Corporate scientists operating outside of regulation in their own interests are willing to go to extreme lengths to cover up what they've done. 


\subsection{Shadow Fury (2001)}

This a B-grade action film based on an evil scientist discovering a way to control the minds of cloned humans. Because of his psychotic tendencies he is thrown out of the Nova Corporation that he works for, and so vows to take revenge on his former colleagues - one who is a mad scientist, one who is immoral and one who is a geek. He secretly creates 'Takeru' - a cloned genetically enhanced fighting machine - and the only way to stop Takeru killing them all is for the scientists to create new clones to fight him.

Best scene: None.

Worst scene: The goodies battle a band of clones, who all have long, long hair brushed over their faces to mask the fact they may not actually look the same, although the other clones tend to be bald.

Accuracy of the science: Low.

Key message: Clones are dangerous and scientists have a tendency to be a little bit evil or mad and sometimes both.

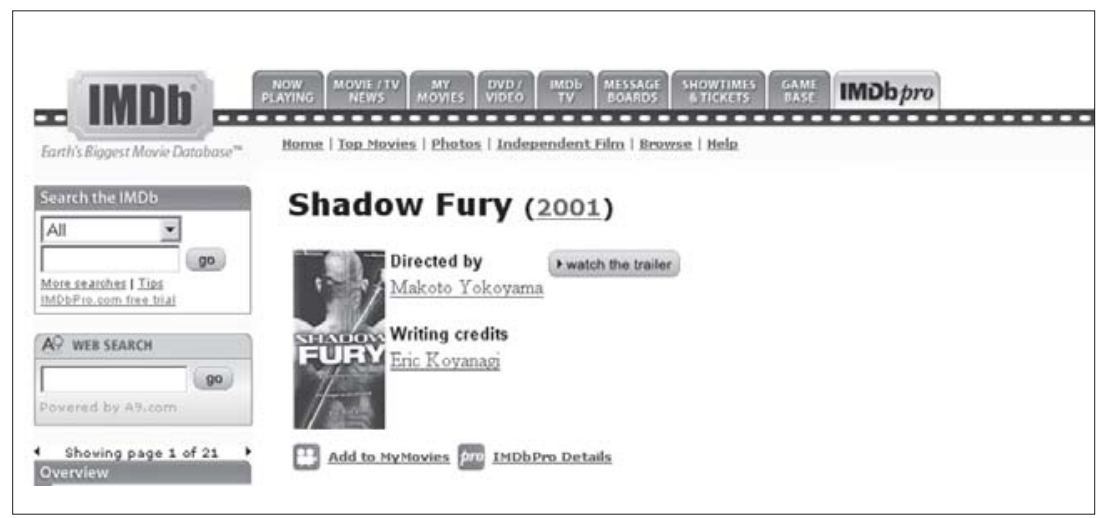

Available at http://amazon.imdb.com/title/tt0288215/

\subsection{The Adventures of Pluto Nash (2002)}

A B-grade comedy that lost more money at the box office than any other film in this study. Production costs were about US $\$ 100,000,000$ and it returned a mere US $\$ 7,000,000$ or $7 \%$. Staring Eddie Murphy, the film is set on the moon where Eddie runs a hip nightclub that the Moon Mafia are trying to take over.

The film rating web site rottentomatoes.com gives it a rotten tomato rating of a mere $6 \%$.

Best scene: Eddie Murphy: “You married twins?” Jay Mohr: “No, I met the perfect woman, so I had her cloned."

Accuracy of the science: Low.

Key message: If you meet the perfect woman, well, then clone her! 


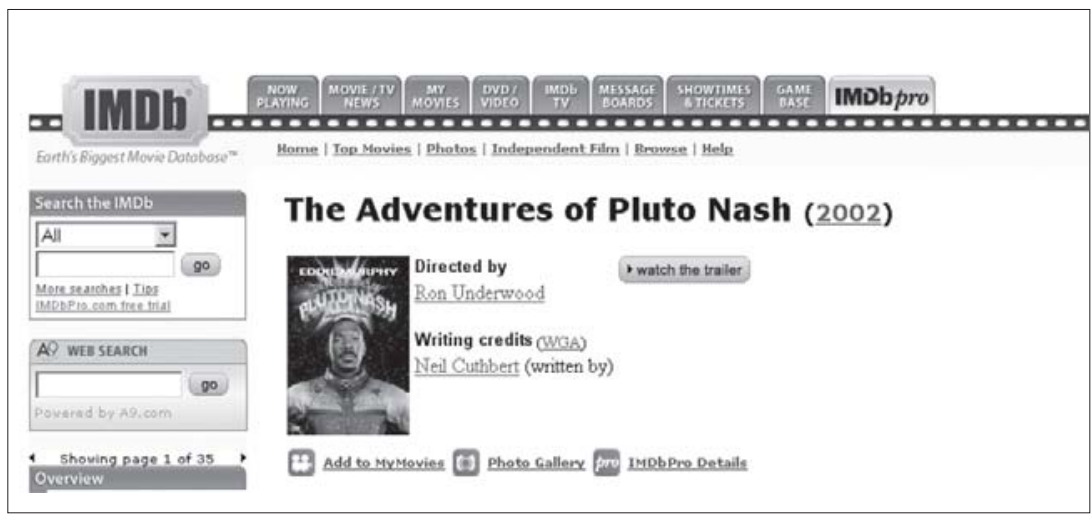

Available at http://amazon.imdb.com/title/tt0180052/

\section{Conclusion}

Overall, scientists hoping to educate the public about the benefits of cloning are facing an uphill battle. According to Charles Colson, writing for Beliefnet, "... it's nearly impossible to name a film where cloning or any other biotech advancement is depicted as unambiguously good" (Colson, 2002). The most common key messages from the cloning films examined is that corporations or scientists operate in their own interests and outside of regulation, and are willing to kill to cover up what they've done. A second key message is that cloning is interfering with nature and is likely to lead to dangerous outcomes. The third predominant message relates to the human rights of a clone, or how a clone might relate to the original human he or she was cloned from.

And looking at the accuracy of the science portrayed in the movies reviewed it is accurate only about a quarter of the time.

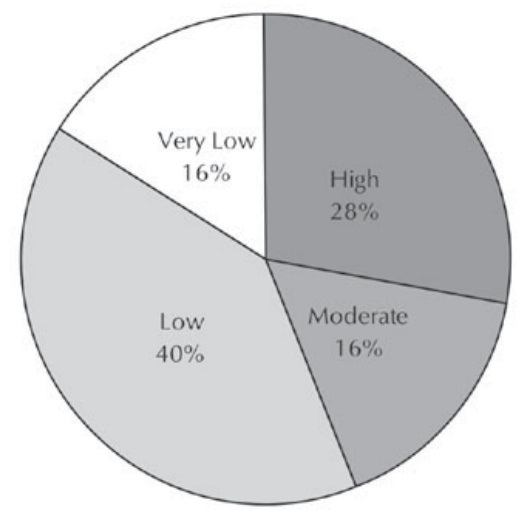

Figure 1 - Accuracy of the science of cloning in movies. 
If we look closely at public attitudes and the negative images and stereotypes depicted in these movies, we see that they actual mirror each other to some extent. The Biotechnology Australia studies found that while there is a very high awareness of cloning, with only $2.2 \%$ not having heard of the term, over $85 \%$ stated that human cloning was not morally acceptable to them. Focus group participants described cloning as "abhorrent", "horrific, mind boggling," and "against nature" (Public Awareness Research).

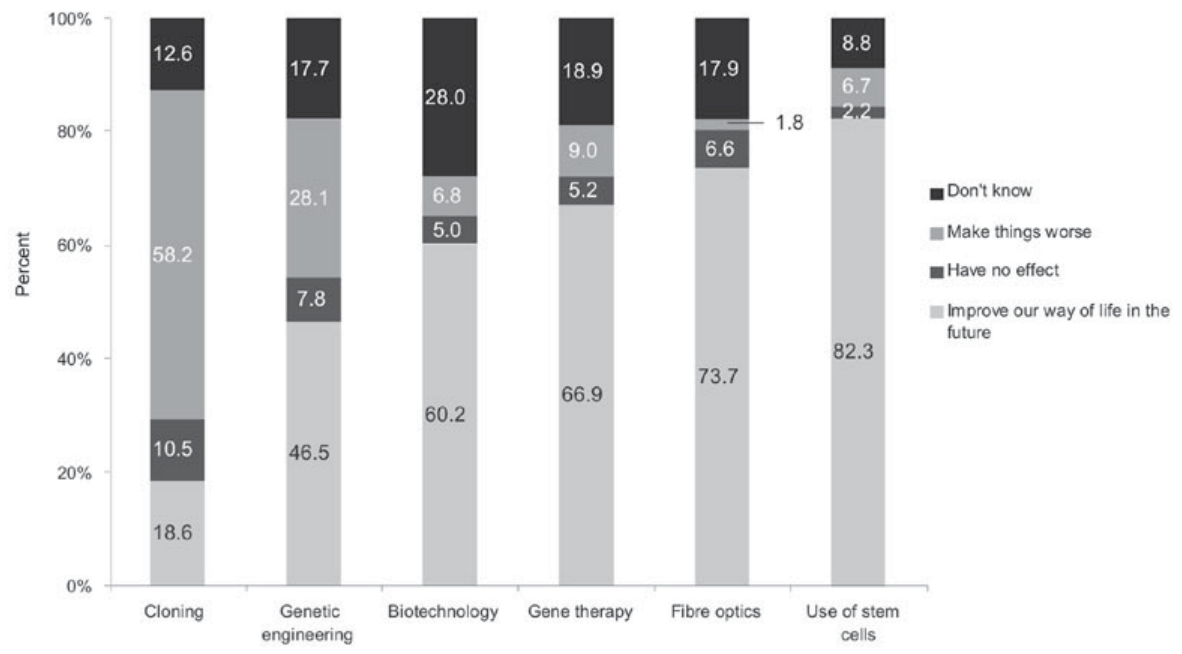

Figure 2 - Perceived impact of technologies.

There was also significant concern about raising clones for body parts, which was seen as raising serious ethical dilemmas. As one focus group participant put it, "You're cloning a human for it to die healthy. The whole idea is not very humane" (ibid.).

U.S. science journalist David Ewan Duncan, has said, "Clearly, the never-ending stream of batty scientist flicks reveals an underlying anxiety and fear about the possible dark side of the technology" (Duncan, op. cit.).

The negative depiction of cloning in films that play upon the worst stereotypes of evil and uncontrolled scientists, fail to challenge us to think seriously about cloning, or consider the types of questions that would have to be considered if human reproductive cloning ever did become a reality. These include issues such as, what would be the rights of a clone? Who should decide who would be cloned? Or how might clones fit into society?

Overall, portrayals of the science of cloning is mixed, but very few movies portray cloning as anything other than evil, dangerous, unnatural and uncontrolled. And while there is not enough 


\section{REFERENCES}

Caplan, Arthur L. 2004

Colson, Charles 2002

Duncan, David Ewing 2004

Film scientists not all mad, bad 2003

Krauss, Lawrence M. 1998

Nottingham, Stephen 1999

Platt, Phil 2002

Public Awareness Research 2005

Rose, Christopher 2003

Science goes spring Hollywood 2004

Shumate, Nathan 2002

The Numbers

The Oxford Student 2005

Weingart, Peter; Muhl, Claudia; Pansegrau, Petra 2003
Godsend no blessing for cloning research. Alden March Bioethics Institute, 30 April.

Hollywood's cloning ethics are ahead of the curve. Beliefnet.

Hollywood takes a look a cloning - and opens up a can of worms. San Francisco Chronicle, 19 April.

Wired News, 28 January.

Beyond Star Trek: physics from alien invasions to the end of time. USA: HarperCollins.

Screening DNA, exploring the cinema-genetics interface.

Bad Movie Science, G4.com, 25 July.

Cloning, Eureka Strategic Research, 2005. (A phone survey of 1067 respondents, supported by 13 focus groups). Available at:

www.biotechnology.gov.au/index.cfm?event=object.showContent\&object ID=71F9EE17-FCAD-2DD8-54B2AAC72192F52A

How to teach biology using the movie science of cloning people, resurrecting the dead, and combining flies and humans.

Public Understanding of Science. Issue 12, p. 289-96, July.

In: The New Atlantis: a journal of technology and society, n. 5, p. 103-5, Spring.

Cold fusion video review.

12 November.

The numbers: box office fata: www.the-numbers.com

Oxford scientist starts firm to target 'bad science' in Hollywood blockbusters'. TT2005.

Of power maniacs and unethical geniuses: science and scientists in fiction film. Public Understanding of Science, Issue 12, p. 279-87, July.

Submitted on March 2006.

Approved on July 2006. 